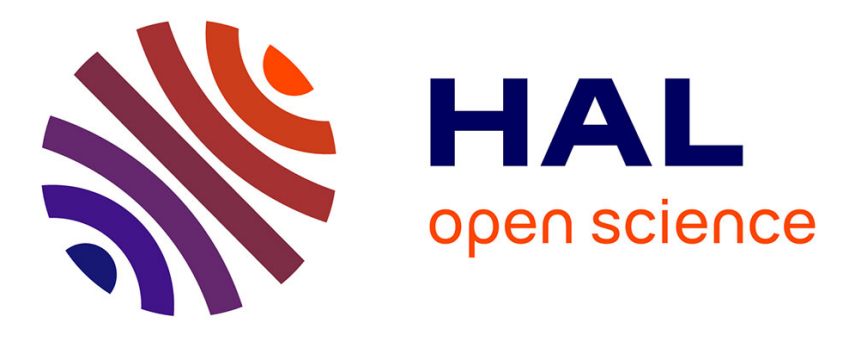

\title{
Bis-imide granulatimide analogues as potent Checkpoint 1 kinase inhibitors.
}

\author{
Hélène Henon, Samir Messaoudi, Fabrice Anizon, Bettina Aboab, N. \\ Kucharczyk, Stéphane Leonce, Roy Golsteyn, Bruno Pfeiffer, Michelle \\ Prudhomme
}

\section{To cite this version:}

Hélène Henon, Samir Messaoudi, Fabrice Anizon, Bettina Aboab, N. Kucharczyk, et al.. Bis-imide granulatimide analogues as potent Checkpoint 1 kinase inhibitors.. European Journal of Pharmacology, 2007, 554, pp.106-112. 10.1016/j.ejphar.2006.10.022 . hal-00119581

\section{HAL Id: hal-00119581 https://hal.science/hal-00119581}

Submitted on 2 Mar 2007

HAL is a multi-disciplinary open access archive for the deposit and dissemination of scientific research documents, whether they are published or not. The documents may come from teaching and research institutions in France or abroad, or from public or private research centers.
L'archive ouverte pluridisciplinaire HAL, est destinée au dépôt et à la diffusion de documents scientifiques de niveau recherche, publiés ou non, émanant des établissements d'enseignement et de recherche français ou étrangers, des laboratoires publics ou privés. 


\title{
Bis-imide granulatimide analogues as potent Checkpoint 1 kinase inhibitors
}

\author{
Hélène Hénon ${ }^{\mathrm{a}}$, Samir Messaoudi ${ }^{\mathrm{a}}$, Fabrice Anizon ${ }^{\mathrm{a}}$, Bettina Aboab ${ }^{\mathrm{a}}$, Nathalie Kucharczyk ${ }^{\mathrm{b}}$, \\ Stéphane Léonce ${ }^{\mathrm{b}}$, Roy M. Golsteyn ${ }^{\mathrm{b}}$, Bruno Pfeiffer ${ }^{\mathrm{b}}$, Michelle Prudhomme ${ }^{\mathrm{a}, *}$ \\ a Laboratoire SEESIB, Université Blaise Pascal, UMR 6504 du CNRS, 63177 Aubière, France \\ ${ }^{\mathrm{b}}$ Institut de Recherches SERVIER, Division Recherche Cancérologie, 125 Chemin de ronde, 78290 Croissy sur Seine, France \\ Received 22 March 2006; received in revised form 5 October 2006; accepted 10 October 2006 \\ Available online 19 October 2006
}

\begin{abstract}
Granulatimide and isogranulatimide, natural products isolated from an ascidian, were found to be abrogators of the cell cycle G2-M phase checkpoint by inhibition of Checkpoint 1 kinase (Chk1). In the course of structure-activity relationship studies on granulatimide analogues, we have synthesized a series of bis-imides, in which the imidazole moiety was replaced by an imide heterocycle. Various modifications have been introduced on one or both imide heterocycles, on the benzene ring, and on the indole nitrogen. Moreover, aza bis-imide analogues were synthesized in which the indole moiety was replaced by a 7-azaindole. Compared to those of granulatimide and isogranulatimide, the Chk1 inhibitory activities of some of the bis-imide carbazoles were stronger. In particular, 1,3,4,6-tetrahydro-10-hydroxy-7 $\mathrm{H}$-dipyrrolo[3,4-a:3,4-c] carbazole-1,3,4,6-tetraone 11 exhibited an $\mathrm{IC}_{50}$ value on purified full length Chk 1 of $2 \mathrm{nM}$, which makes it a more potent Chk1 inhibitor than granulatimide and isogranulatimide. To get an insight into the selectivity of this new family of compounds, the inhibitory activities of $1,3,4,6-$ tetrahydro-7H-dipyrrolo[3,4- $a: 3,4-c]$ carbazole-1,3,4,6-tetraone $\mathbf{A}$ have been evaluated on a panel of 15 kinases, the strongest inhibitory potency was found for Chk1. The inhibitory activities of compounds $\mathbf{A}, \mathbf{5}$ and $\mathbf{1 1}$ toward Src tyrosine kinase and the cytotoxicity of various tumor cell lines were also evaluated.
\end{abstract}

(C) 2006 Elsevier B.V. All rights reserved.

Keywords: Granulatimide; Isogranulatimide; Antitumor agent; Chk1 inhibitor

\section{Introduction}

Cell division of eukaryotic cells is a highly regulated process in which many pathways participate to maintain genome integrity. When DNA is damaged, cells respond by activating checkpoint pathways that cause an arrest in the cell cycle progression to allow time for DNA repair. Ataxia-Telangiectasia Mutated (ATM) and Ataxia-Telangiectasia Related (ATR) kinases are central components of the DNA damage response in the S phase and G2-M checkpoints, which activate Chk1 and Chk2 kinases (Zhou and Elledge, 2000; Luo et al., 2001; Molinari, 2000). Chk1 kinase, initially identified in 1993 (Walworth et al., 1993) has triggered considerable interest in the past decade as a target for the design of novel antitumor agents.

\footnotetext{
* Corresponding author. Tel.: +3347340 71 24; fax: +3347340 7717 .

E-mail address: Michelle.PRUDHOMME@univ-bpclermont.fr (M. Prudhomme)
}

Indeed, it has been shown that $\mathrm{G} 2$ abrogation can sensitize p53mutated cells to DNA-damaging cancer therapeutic agents. In more than $50 \%$ of human tumors, p53 is mutated, therefore leading to G1 checkpoint deficiencies. It is believed that subsequent inhibition of the $\mathrm{G} 2$ checkpoint in combination with a DNA-damaging agent could selectively induce the death of cancer cells (Suganuma et al., 1999; Prudhomme, 2004).

Various Chk1 inhibitors have been reported in the literature (Anderson et al., 2003) and more recently in several patents (Prudhomme, 2006; Tao and Lin, 2006). Among these molecules aminopyrazoles, pyrimidines and ureas possess $\mathrm{IC}_{50}$ values toward Chk1 in the nanomolar range.

The crystal structure of the human Chk1 KD apoenzyme and its binary complex with an ATP analogue has been determined (Chen et al., 2000). More recently, the crystal structures of Chk1 in complex with several ATP competitive inhibitors, staurosporine, UCN-01, SB-218078, and isogranulatimide have also been resolved (Zhao et al., 2002; Jiang et al., 2004) (Fig. 1). 


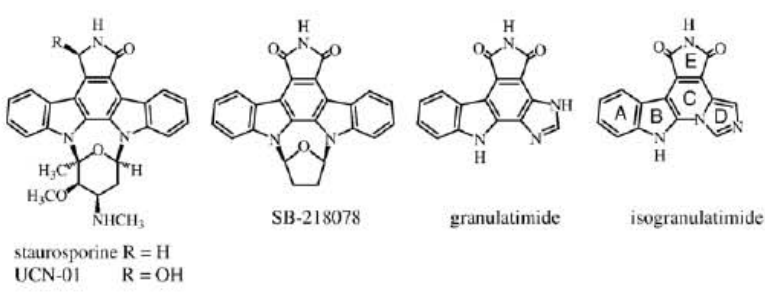

Fig. 1. Chemical structures of staurosporine, UCN-01, SB-218078, granulatimide and isogranulatimide.

Granulatimide and isogranulatimide are natural compounds isolated from the ascidian Didemnum granulatum possessing Chk1 inhibitory properties (Berlinck et al., 1998; Roberge et al., 1998; Jiang et al., 2004). In the crystal structure of Chk1 in complex with isogranulatimide, as well as in those of Chk1 in complex with staurosporine, UCN-01, SB-218078, hydrogen bonds are observed between the lactam or the imide $\mathrm{NH}$ of the drug and the carbonyl of $\mathrm{Glu}^{85}$ and between the carbonyl of the imide or lactam and $\mathrm{Cys}^{87}$ in the ATP binding site of the enzyme. Isogranulatimide isomers and closely related compounds have been synthesized (Piers et al., 2000; Yoshida et al., 2002, 2003).

In the course of structure-activity relationship studies on granulatimide analogues, we have synthesized compounds in which the imidazole heterocycle was replaced by a pyrrole or an imide moiety, as well as compounds in which the indole unit was replaced by a 7-azaindole unit (Hugon et al., 2003a,b,c). Concerning the bis-imide analogues, substitutions were carried out either on the indole moiety or on the imide nitrogens (Fig. 2). The syntheses were performed either by conventional methods or using parallel solution-phase method and microwave irradiation (Hénon et al,, 2005, 2006a,b,c). The Chk1 inhibitory activities of several bis-imides substituted in the 10 position of the indole moiety with various saturated and unsaturated side chains, synthesized via palladium catalysed crosscoupling reactions, have been evaluated (Hénon et al., 2006c). The most efficient Chk1 inhibitor was compound B (Fig. 2), which has a methyl substituent at the 10 position with an $\mathrm{IC}_{50}$ value toward Chk 1 of $8 \mathrm{nM}$.

In this paper, the Chk1 inhibitory activities of bis-imide granulatimide analogues modified on the indole moiety, on the imide heterocycles, as well as those of 7-azaindole bis-imides are described (Fig. 3, Table 1) together with their antiproliferative activities toward five tumor cell lines in vitro: murine leukemia L1210, human DU145 prostate carcinoma, A549 nonsmall cell lung carcinoma and HCT116 and HT29 colon carci-

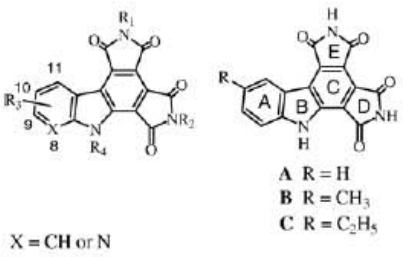

Fig. 2. Bis-imide granulatimide analogues. nomas $\left(\mathrm{IC}_{50} \mu \mathrm{M}\right)$. The possible interactions with the ATP binding site of Chk 1 were investigated by molecular modelling for some of our bis-imides. To get insight into the kinase selectivity of this family of compounds, the inhibitory activities of the nude bis-imide A were evaluated with a panel of 15 kinases. The percentages of activity of various kinases: Checkpoint 1 kinase (Chk1), AMP-activated protein kinase (AMPK), $\mathrm{Ca}^{2+} /$ calmodulin dependent protein kinase II (CAM$\mathrm{KII})$, casein kinase I (CKI), fibroblast growth factor receptor 3 (FGFR3), glycogen synthase kinase 3 (GSK3), lymphocytespecific protein tyrosine kinase (LCK), MAP kinase 1 (MAPK1), mitogen-activated protein kinase-activated protein kinase 2 (MAPKAPK2), kinase responsible for site specific phosphorylation of BAD (P70S6K), protein kinase A (PKA), protein kinases $\mathrm{C} \beta, \alpha, \varepsilon$ isoforms (PKC $\beta, \mathrm{PKC} \alpha, \mathrm{PKC} \varepsilon$ ) were determined at a concentration of $1 \mu \mathrm{M}$ (Table 2). The inhibitory activities of the bis-imides $\mathbf{A}, \mathbf{5}$, and $\mathbf{1 1}$, toward Sre tyrosine kinase were also examined. The percentages of Src kinase inhibition were determined (Table 3).

\section{Materials and methods}

\subsection{Kinase inhibition assays}

Chk1 inhibition assays: Human Chk1 full-length enzyme with a N-terminal GST sequence was either purchased from
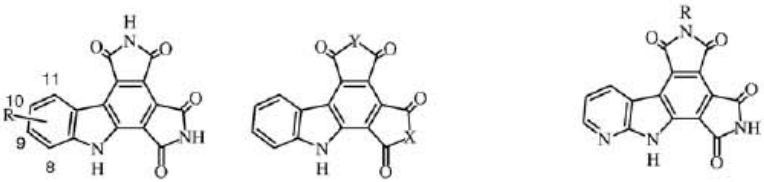

$1 \mathrm{R}=8-\mathrm{CH}_{3}$

$2 \mathrm{R}=8-\mathrm{OBn}$

$2 \mathrm{R}=8-\mathrm{F}$
$\mathrm{R}=9-\mathrm{O}$

$3 \mathrm{R}=9-\mathrm{F}$
$4 \mathrm{R}=9-\mathrm{Cl}$

$\begin{aligned} 4 \mathrm{R} & =9-\mathrm{Cl} \\ 5 \mathrm{R} & =9-\mathrm{Br}\end{aligned}$

$6 \mathrm{R}=9-\mathrm{CH}_{3}$

$7 \mathrm{R}=9-\mathrm{OH}$

$8 \mathrm{R}=10-\mathrm{Br}$

$9 \mathrm{R}=10-\mathrm{I}$

$10 \mathrm{R}=10-\mathrm{OB}$

$10 \mathrm{R}=10-\mathrm{OB}$
$11 \mathrm{R}=10-\mathrm{OH}$

$12 \mathrm{R}=11-\mathrm{OCH}_{3}$

$13 \mathrm{X}=\mathrm{NCH}_{3}, \mathrm{Y}=\mathrm{NH}$

$14 \mathrm{X}=\mathrm{NCH}_{3}, \mathrm{Y}=\mathrm{O}$

$22 \mathrm{R}=\mathrm{H}$

$15 \mathrm{X}=\mathrm{NCH}_{3}, \mathrm{Y}=\left(\mathrm{CH}_{2}\right)_{2}-\mathrm{NEt}_{2} . \mathrm{HCl}$

$16 \mathrm{X}=\mathrm{Y}=\mathrm{NCH}_{3}$

$17 \mathrm{X}=\mathrm{O}, \mathrm{Y}=\mathrm{NH}$

$18 \mathrm{X}=\mathrm{O}, \mathrm{Y}=\mathrm{NCH}_{3}$

$19 \mathrm{X}=\mathrm{NH}, \mathrm{Y}=\mathrm{NCH}_{3}$

$20 \mathrm{X}=\mathrm{NH}, \mathrm{Y}=\mathrm{O}$

$21 \mathrm{X}=\left(\mathrm{CH}_{2}\right)_{2}-\mathrm{NEt}_{2} . \mathrm{HCl}, \mathrm{Y}=\mathrm{NCH}_{3}$

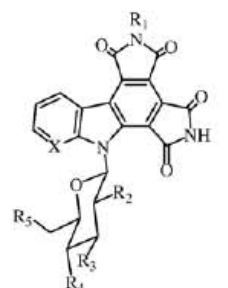

$24 \mathrm{X}=\mathrm{CH}, \mathrm{R}_{1}=\mathrm{H}, \mathrm{R}_{2}=\mathrm{R}_{3}=\mathrm{R}_{4}=\mathrm{R}_{5}=\mathrm{OH}$

$25 \mathrm{X}=\mathrm{CH}, \mathrm{R}_{1}=\mathrm{H}, \mathrm{R}_{2}=\mathrm{R}_{3}=\mathrm{R}_{4}=\mathrm{R}_{5}=\mathrm{OAC}$

$26 \mathrm{X}=\mathrm{CH}, \mathrm{R}_{1}=\mathrm{H}, \mathrm{R}_{2}=\mathrm{R}_{3}=\mathrm{R}_{4}=\mathrm{OH}, \mathrm{R}_{5}=\mathrm{Cl}$

$27 \mathrm{X}=\mathrm{CH}, \mathrm{R}_{1}=\mathrm{H}, \mathrm{R}_{2}=\mathrm{R}_{3}=\mathrm{R}_{4}=\mathrm{OH}, \mathrm{R}_{5}=\mathrm{N}_{3}$

$28 \mathrm{X}=\mathrm{CH}, \mathrm{R}_{1}=\mathrm{H}, \mathrm{R}_{2}=\mathrm{R}_{3}=\mathrm{R}_{4}=\mathrm{OH}, \mathrm{R}_{5}=\mathrm{NH}_{2} . \mathrm{HCl}$

$29 \mathrm{X}=\mathrm{N}, \mathrm{R}_{1}=\mathrm{H}, \mathrm{R}_{2}=\mathrm{R}_{3}=\mathrm{R}_{4}=\mathrm{R}_{5}=\mathrm{OH}$

$30 \mathrm{X}=\mathrm{N}, \mathrm{R}_{1}=\mathrm{CH}_{3}, \mathrm{R}_{2}=\mathrm{R}_{3}=\mathrm{R}_{4}=\mathrm{R}_{5}=\mathrm{OH}$

$31 \mathrm{X}=\mathrm{N}, \mathrm{R}_{1}=\mathrm{CH}_{2} \mathrm{OH}, \mathrm{R}_{2}=\mathrm{R}_{3}=\mathrm{R}_{4}=\mathrm{R}_{5}=\mathrm{OH}$

Fig. 3. Structure of the various bis-imides. 
Table 1

Percentages of Chk1 inhibition at a drug concentration of $10^{-5} \mathrm{M}, \mathrm{IC}_{50}$ values $(\mu \mathrm{M})$ toward Chk1

\begin{tabular}{|c|c|c|c|c|c|c|c|}
\hline \multirow[t]{2}{*}{ Compound } & \multirow{2}{*}{$\frac{\% \text { Inhibition }}{\text { Chk1 at } 10^{-5} \mathrm{M}}$} & \multirow{2}{*}{$\frac{\mathrm{IC}_{50}}{\operatorname{Chk1}(\mu \mathrm{M})}$} & \multirow[t]{2}{*}{$\mathrm{L} 1210^{\mathrm{a}}$} & \multirow[t]{2}{*}{ DU145 ${ }^{\mathrm{a}}$} & \multirow[t]{2}{*}{$\mathrm{A} 549^{\mathrm{a}}$} & \multirow[t]{2}{*}{ HCT $116^{a}$} & \multirow[t]{2}{*}{ HT $29^{a}$} \\
\hline & & & & & & & \\
\hline Granulatimide & 93.9 & 0.081 & 2.8 & 2.8 & 11.4 & nd & 5.7 \\
\hline Isogranulatimide & 89.7 & 0.438 & 10 & 13.1 & 18.1 & nd & 13.7 \\
\hline A & 94.4 & 0.017 & 32.7 & 53.6 & 65.7 & nd & 9.7 \\
\hline B & 91.1 & 0.0087 & 1.8 & nd & nd & 2.2 & 3.29 \\
\hline $\mathrm{C}$ & 75.8 & 5 & 5.9 & nd & nd & 7.6 & 16.4 \\
\hline 1 & 44.2 & & 18.5 & nd & nd & 40.9 & 84.3 \\
\hline 2 & 10.9 & & 2.7 & 17.1 & nd & nd & 18.6 \\
\hline 3 & 87.0 & 0.068 & 7.3 & nd & nd & 8.6 & 20.0 \\
\hline 4 & 91.1 & 0.0345 & 0.9 & nd & nd & 1.5 & 9.8 \\
\hline 5 & 80.6 & 0.011 & 0.7 & 3.06 & nd & nd & 3.1 \\
\hline 6 & 74.9 & 0.0366 & 2.2 & nd & nd & 4.9 & $>100$ \\
\hline 7 & 94.4 & 0.135 & 42.2 & nd & nd & 16.4 & 42.5 \\
\hline 8 & 90.2 & 0.0327 & 3.61 & 10.1 & nd & nd & 20 \\
\hline 9 & nd & & nd & nd & nd & nd & nd \\
\hline 10 & 53.9 & 5 & 3.37 & 3.7 & nd & nd & 3.7 \\
\hline 11 & 97.1 & 0.002 & 54.7 & 71.9 & 62.9 & nd & nd \\
\hline 12 & 23.1 & & 17.1 & nd & nd & 14.5 & 26.6 \\
\hline 13 & 75.7 & 5 & 5.47 & 6.77 & 6.47 & nd & 10.6 \\
\hline 14 & 39.6 & & 26 & 20.7 & 23.8 & nd & 11.2 \\
\hline 15 & 11.89 & & 45.3 & 43.1 & 31.7 & nd & 46.7 \\
\hline 16 & 22.2 & & 8.3 & 16 & 9.5 & nd & 12.9 \\
\hline 17 & 46.7 & & $>50$ & $>50$ & $>50$ & nd & 24.2 \\
\hline 18 & 24.3 & & 67.5 & $>100$ & $>100$ & nd & 56.1 \\
\hline 19 & 30.7 & & 61.2 & 23.7 & 20.1 & nd & 30.3 \\
\hline 20 & -6.6 & & 11.9 & nd & nd & 10.7 & 33.0 \\
\hline 21 & 13.9 & & 59.3 & 67.8 & 44.1 & nd & 51.5 \\
\hline 22 & 67.6 & 5 & 17.9 & nd & nd & 7.0 & 10.6 \\
\hline 23 & -17.5 & & 21.7 & 12.2 & nd & nd & 9 \\
\hline 24 & 83.2 & 0.145 & 45.4 & nd & nd & 68.5 & 56.1 \\
\hline 25 & 36.8 & & 64.3 & nd & nd & 89.0 & $>100$ \\
\hline 26 & 76.5 & 0.387 & 40.8 & nd & nd & 54.2 & 42.9 \\
\hline 27 & 74.4 & 2.15 & 63.8 & nd & nd & 94.5 & $>100$ \\
\hline 28 & 56.8 & 1.44 & 83.9 & nd & nd & nd & 46.3 \\
\hline 29 & 14.4 & & 109 & nd & nd & 73.6 & 21.8 \\
\hline 30 & 14.9 & & 18.1 & nd & nd & 29.3 & 29.3 \\
\hline 31 & 56.0 & 5 & 17.9 & nd & nd & 7.0 & 10.6 \\
\hline
\end{tabular}

In vitro antiproliferative activities against five tumor cell lines: one murine leukemia L1210, and human DU145 prostate carcinoma, A549 non-small cell lung carcinoma and HCT116 and HT29 colon carcinoma ( $\left.\mathrm{IC}_{50} \mu \mathrm{M}\right)$.

nd: not determined.

a The cytotoxicities could be due to breakdown products.

Upstate Biochemicals (No. 14-346). Assays for compound testing were based upon the method described by Davies et al. (2000).

Src inhibition assays: Inhibitors were diluted with a Tecan Evo 150 robot. The kinase assay was performed with $4 \mu \mathrm{l}$ of inhibitor ( $10 \%$ dimethylsulfoxide (DMSO)), $10 \mu \mathrm{l}$ of kinase assay buffer $4 \times$ concentrated $(80 \mathrm{mM} \mathrm{MgCl} 2,200 \mathrm{mM} \mathrm{4-(2-}$ hydroxyethyl)-1-piperazineethanesulfonic acid (HEPES),
$0.4 \mathrm{mM}$ ethylenediamine-tetraacetic acid (EDTA), $2 \mathrm{mM}$ DLdithiothreitol (DTT)), $10 \mu \mathrm{l}$ substrate peptide (KVEKIGEGYYGVVYK, $370 \mathrm{nM}$ ) and $6 \mu \mathrm{l}$ Src kinase (stock GTP purified diluted with $1 \times$ kinase assay buffer to $200 \mathrm{nM}$ ). $10 \mu \mathrm{l}$ cosubstrate $\left(40 \mu \mathrm{M}\right.$ ATP with $0.2 \mu \mathrm{Ci} \mathrm{P}^{33}-\gamma$-ATP) was added with a Precision 2000 (Biotek Robotic). The assay was incubated for $20 \mathrm{~min}$ at $30{ }^{\circ} \mathrm{C}$ then stopped by adding $200 \mu \mathrm{l} 0.85 \%$ orthophosphoric acid, then transferred to a phosphocellulose

Table 2

Inhibitory activity of the lead bis-imide $\mathbf{A}$ toward 15 kinases

\begin{tabular}{|c|c|c|c|c|c|c|c|c|c|c|c|c|c|c|c|}
\hline Compound & Chk1 & AMPK & CAMKII & CDK2/cyclin A & CKI & FGFR3 & GSK3 & LCK & MAPK1 & MAPKAPK2 & P70S6K & PKA & PKC $\beta$ & $\mathrm{PKC} \alpha$ & $\mathrm{PKC} \varepsilon$ \\
\hline A & 5 & 48 & 84 & 42 & 97 & 35 & 11 & 83 & 86 & 95 & 81 & 99 & 91 & 67 & 91 \\
\hline
\end{tabular}

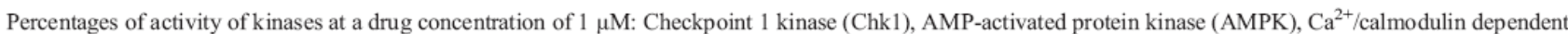
protein kinase II (CAMKII), casein kinase I (CKI), fibroblast growth factor receptor 3 (FGFR3), glycogen synthase kinase 3 (GSK3), lymphocyte-specific protein tyrosine kinase (LCK), MAP kinase 1 (MAPK1), mitogen-activated protein kinase-activated protein kinase 2 (MAPKAPK2), kinase responsible for site specific phosphorylation of BAD (P70S6K), protein kinase A (PKA), protein kinases $\mathrm{C} \beta, \alpha, \varepsilon$ isoforms (PKC $\beta, \mathrm{PKC} \alpha, \mathrm{PKC} \varepsilon$ ). 
filter microplate (Whatman-P81). The plate was washed 3 times with $200 \mu \mathrm{l} 0.85 \%$ orthophosphoric acid dried with $200 \mu \mathrm{l}$ acetone. The remaining activity was measured on a Topcount with $25 \mu \mathrm{l}$ scintillation solution (Packard UltimaGold).

Inhibition assays toward other kinases were performed by Upstate's kinase profiler screening service (Dundee, Scotland).

\subsection{Growth inhibition assays}

Tumor cells were provided by American Type Culture Collection (Frederick, MD, USA). They were cultivated in RPMI 1640 medium (Life Science technologies, Cergy-Pontoise, France) supplemented with $10 \%$ fetal calf serum, $2 \mathrm{mM} \mathrm{L}-$ glutamine, $100 \mathrm{U} / \mathrm{ml}$ penicillin, $100 \mu \mathrm{g} / \mathrm{ml}$ streptomycin, and $10 \mathrm{mM}$ HEPES buffer $(\mathrm{pH}=7.4)$. Cytotoxicity was measured by the microculture tetrazolium assay as described (Léonce et al., 1996). Cells were continuously exposed to graded concentrations of the compounds for four doubling times, then $15 \mu \mathrm{l}$ of $5 \mathrm{mg} / \mathrm{ml}$ 3-(4,5-dimethylthiazol-2-yl)-2,5-diphenyltetrazolium bromide was added to each well and the plates were incubated for $4 \mathrm{~h}$ at $37^{\circ} \mathrm{C}$. The medium was then aspirated and the formazan solubilized by $100 \mu \mathrm{l}$ of DMSO. Results are expressed as $\mathrm{IC}_{50}$, concentration which reduced by $50 \%$ the optical density of treated cells with respect to untreated controls.

\subsection{Molecular modelling}

All molecular mechanics calculations were performed by the Macromodel [26] molecular modelling software. We used as model the complex structure of CHK1/STAUROSPORINE [6] downloaded from the Protein Data Bank (1NVR file).

Energy minimisation was done with AMBER force field [27, 28] using the Truncated Newton Conjugate Gradient method (TNCG).

\section{Results}

\subsection{Inhibitory activities toward Chk1}

The percentages of Chk1 inhibition were evaluated at a drug concentration of $10^{-5} \mathrm{M}$. For the most efficient compounds, the $\mathrm{IC}_{50}$ values were determined and compared with those of granulatimide, isogranulatimide and compounds $\mathbf{A}-\mathbf{C}$ (Hénon et al., 2006c), bearing a methyl or an ethyl group at the 10 position, respectively (Table 1 ). The cytotoxicities toward five tumor cell lines: one murine leukemia L1210 and four human tumor cell lines, DU145 prostate carcinoma, A549 non-small cell lung carcinoma and HCT116 and HT29 colon carcinoma. The $\mathrm{IC}_{50}$ values are expressed in $\mu \mathrm{M}$.

Concerning the substitutions at various positions of the indole moiety (compounds 1-12), all the compounds tested exhibit strong inhibitory activities toward Chk1, except compounds 1 and 2 , substituted in the 8 position. Since a methyl group in the 9 or 10 positions is compatible with Chk1 inhibition (compounds $\mathbf{6}$ and B), it can be assumed that substitutions in the 8 position are not favoured.
Table 3

Inhibitory activities of bis-imides $\mathbf{A}, \mathbf{5}$ and $\mathbf{1 1}$ toward Src kinase

$\begin{array}{llll}\text { Compounds at a drug concentration }(\mu \mathrm{M}) & \mathbf{A}(10 \mu \mathrm{M}) & \mathbf{5}(4 \mu \mathrm{M}) & \mathbf{1 1}(4 \mu \mathrm{M})\end{array}$

$\begin{array}{llll}\% \text { Inhibition } & 35.6 & 66 & 32.3\end{array}$

Percentages of Src inhibition at a given drug concentration.

Substitutions in the 9 position with halogens, methyl or hydroxy substituents are compatible with Chk1 inhibition but, compared with the unsubstituted compound $\mathbf{A}$, they did not induce significant improvement. With halogen atoms in the 9 position, the following sequence of efficiency is observed $\mathrm{Br}$ (compound 5) $>\mathrm{Cl}$ (compound 4) $>\mathrm{F}$ (compound 3 ).

Substitutions in the 10 position are favoured (compounds 8 and 11). Compound $\mathbf{1 1}$ with a hydroxy group is a much stronger Chk1 inhibitor than compound 10, bearing a benzyloxy substituent. 1,3,4,6-Tetrahydro-10-hydroxy-7H-dipyrrolo[3,4-a:3,4$c$ carbazole-1,3,4,6-tetraone $\mathbf{1 1}$ is the most efficient Chk1 inhibitor in this bis-imide series with an $\mathrm{IC}_{50}$ value of $2 \mathrm{nM}$.

A methyloxy substituent in the 11 position is detrimental to Chk1 inhibition. Unfortunately, some compounds, 11-OBn, 10F, 10-Cl, 10-I, and $10-\mathrm{CO}_{2} \mathrm{CH}_{3}$, could not be tested due to their insolubility.

All of the compounds bearing modified imides (compounds 13-21) were poor Chk1 inhibitors except compound 13, in which the upper imide is not substituted. However, compound 13 was a much weaker Chk 1 inhibitor than compound $\mathbf{A}$, suggesting that substitution of the lower imide nitrogen was also detrimental to Chk1 inhibition. Replacement of the upper imide function by an anhydride, or substitution of the upper imide nitrogen with a methyl or a $N, N$-diethylaminoethyl group abolished the Chk1 inhibitory properties. The aza bis-imide analogue 22 presented a Chk1 inhibitory activity in the micromolar range. However, the replacement of the indole moiety by a 7azaindole strongly weakened the activity toward Chk1 (compare compounds $\mathbf{2 2}$ and $\mathbf{A}$ ). As observed in the non-aza series, in the aza series, the substitution of the upper imide nitrogen with a methyl group completely abolished the Chk1 inhibitory properties.

Bis-imide analogues bearing a sugar part in the non-aza and aza series were synthesized. The sugar moiety was expected to increase compound solubility by forming supplementary hydrogen bonds in the ATP binding pocket, as observed in the crystal structure of UCN-01/Chk1 complex (Zhao et al., 2002). However, the glycosylation, except for hydrochloride 28, did not improve significantly the solubility. In the non-aza series (compounds 24-28), compound 24 without modifications of the glucosyl unit was the most efficient Chk 1 inhibitor. The sugar moiety did not enhance Chk1 inhibition (compare compounds $\mathbf{2 4}$ and $\mathbf{A}$ ). The replacement of hydroxy functions on the sugar by acetoxy groups strongly weakened the Chk1 inhibitory potency. These ester functions were introduced to allow a better cell penetration as reported for indigo derivatives (Wang et al., 2003). They are expected to be cleaved inside the cells by enzymes such as esterases to give the hydroxy functions. But the weaker cytotoxicities of compound $\mathbf{2 5}$ toward the tumor cell line tested compared to those of compound $\mathbf{2 4}$, suggest that 
compound $\mathbf{2 5}$ does not function as a prodrug for compound $\mathbf{2 4}$. Chloro, azido and amino groups as $\mathrm{R}_{5}$ did not improve Chk1 inhibitory activity (compare the $\mathrm{IC}_{50}$ values for compounds $\mathbf{2 6}$ and 28 with that of compound 24). In the aza series, compared with its non-aza analogue $\mathbf{2 4}$, compound $\mathbf{2 9}$ has lost the capacity to inhibit Chk1. As previously observed with compounds bearing a methyl group at the upper imide nitrogen, compound 30 showed low activity against Chk1. Interestingly the most efficient compound in the aza series bearing a sugar unit is compound 31, substituted at the upper imide nitrogen with a hydroxymethyl group, exhibiting a Chk1 inhibitory activity in the micromolar range.

3.2. Inhibitory activities of compounds A, 5, and $\mathbf{1 1}$ toward a panel of other kinases

To evaluate the selectivity of this family of compounds, the inhibitory activities of bis-imide A toward various other kinases (AMPK, CAMKII, CKI, FGFR3, GSK3, LCK, MAPK1,
MAPKAPK2, P70S6K, PKA, PKC $\beta, P K C \alpha, P K C \varepsilon$ reported in Table 2) were evaluated. Interestingly, the strongest inhibition was found toward Chk1, which confirms the specificity of this compound on this panel. Moreover, the inhibitory activities of compounds $\mathbf{A}, \mathbf{5}$ and $\mathbf{1 1}$ toward Src tyrosine kinase were examined. The percentages of Src inhibition were determined at a given drug concentration (10 $\mu \mathrm{M}$ for $\mathbf{A}$ and $4 \mu \mathrm{M}$ for 5 and 11) (Table 3 ). In contrast with their high inhibitory activities toward Chk1, these three compounds did not exhibit strong inhibitory properties toward Src.

3.3. In vitro antiproliferative activities against five tumor cell lines: murine L1210, human DU145, A549, HCT116 and HT29

The antiproliferative activities against cell lines in vitro were evaluated. The $\mathrm{IC}_{50}$ values in $\mu \mathrm{M}$ are given in Table 1 . It can be noticed that most of the tested compounds were not strongly cytotoxic. For example, the cytotoxicities of compound $\mathbf{A}$, a potent Chk1 inhibitor with an $\mathrm{IC}_{50}$ value of $17 \mathrm{nM}$, and

B

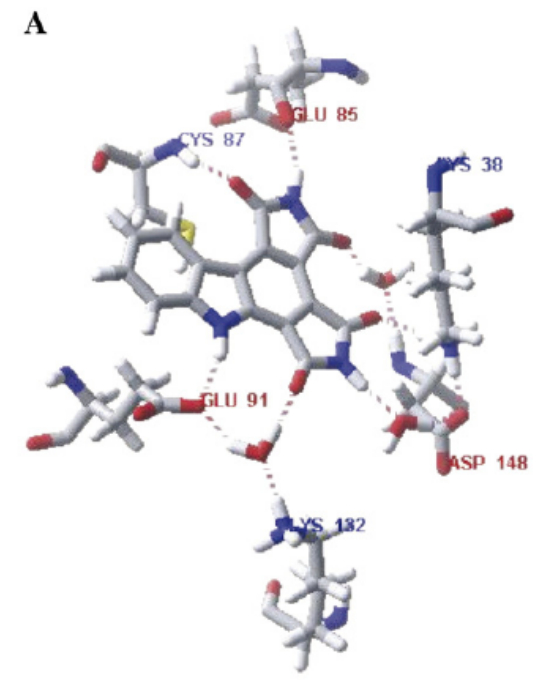

C

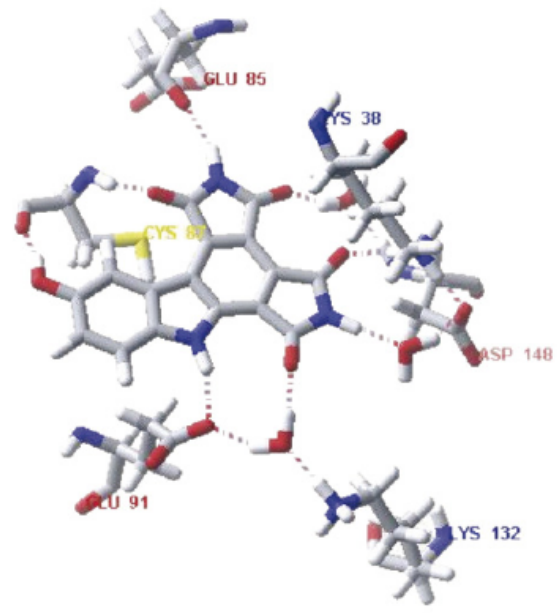

D

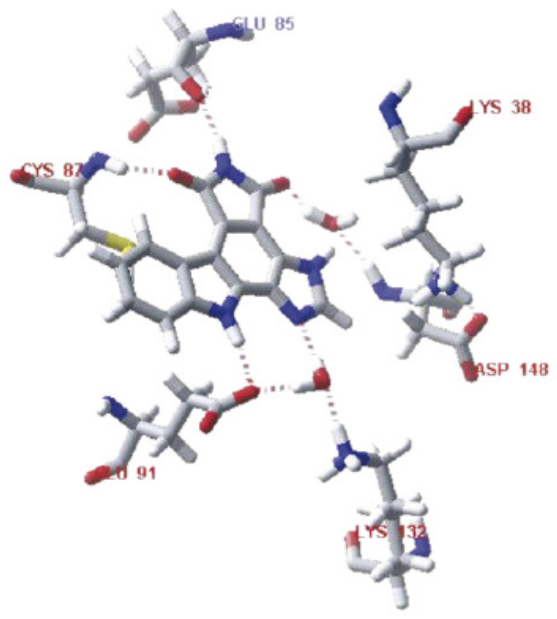

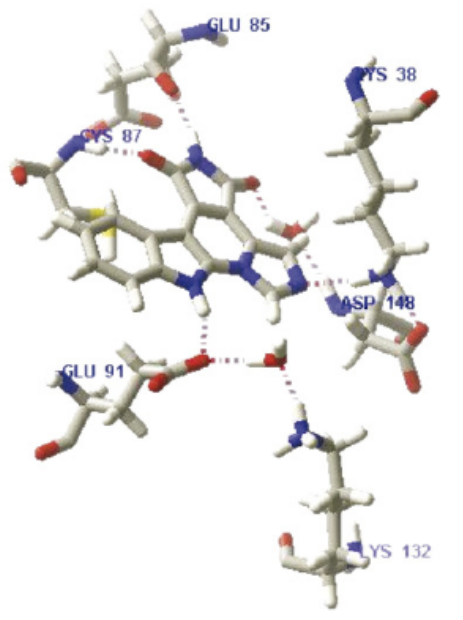

Fig. 4. Molecular modelling of bis-imides A (A) and 11 (B), granulatimide (C), and isogranulatimide (D) in the ATP binding site of Chk1. 
compound $\mathbf{1 1}\left(\mathrm{IC}_{50}\right.$ toward $\left.\mathrm{Chk} 1: 2 \mathrm{nM}\right)$ toward the tumor cell lines tested are moderate. The highest cytotoxicities were observed for compounds $\mathbf{B}, \mathbf{4}, \mathbf{5}$ bearing $10-\mathrm{CH}_{3}, 9-\mathrm{Cl}$ and $9-\mathrm{Br}$ substituents on the indole moiety, respectively.

\section{Discussion}

From our results, it appears that some bis-imides are considerably stronger Chk1 inhibitors than their parent natural compounds granulatimide and isogranulatimide. That could be explained by more affinity for the enzyme. To get an insight into the mode of binding of our bis-imides compared with granulatimide and isogranulatimide, molecular modelling of granulatimide, isogranulatimide and our bis-imides $\mathbf{A}$ and $\mathbf{1 1}$ was carried out into the ATP binding pocket of Chk1 (Fig. 4). With bis-imide A (Fig. 4A), seven hydrogen bonds were observed. In addition to the two fundamental hydrogen bonds between the carbonyl on the left and the imide $\mathrm{NH}$ of the $\mathrm{E}$ heterocycle with $\mathrm{Cys}^{87}$ and $\mathrm{Glu}^{85}$ respectively, hydrogen bonds were also observed between the indole $\mathrm{NH}$ and the carboxylate of the side chain of $\mathrm{Glu}^{91}$, and between the upper carbonyl of the D heterocycle and the amine of the side chain of Lys ${ }^{38}$. Moreover three hydrogen bonds are formed via a water molecule: between the carbonyl on the left of the $\mathrm{E}$ heterocycle and the $\mathrm{NH}$ of $\mathrm{Asp}^{148}$, between the imide $\mathrm{NH}$ of the D heterocycle and the carboxylate of the side chain of $\mathrm{Asp}^{148}$, and between the lower carbonyl of the D heterocycle and the amine of the side chain of Lys ${ }^{132}$ and the carboxylate of the side chain of $\mathrm{Glu}^{91}$. The important hydrogen bond network is in agreement with the strong inhibitory activity of bis-imide $\mathbf{A}$ toward Chk1 $\left(\mathrm{IC}_{50}\right.$ value: $\left.20 \mathrm{nM}\right)$. The same hydrogen bond network was observed with bis-imide 11 (Fig. 4B), with an additional hydrogen bond between the 10-OH and the carbonyl of $\mathrm{Cys}^{87}$ which could account for the stronger Chk1 inhibitory activity of compound $11(2 \mathrm{nM})$. With granulatimide, molecular modelling (Fig. 4C) showed a similar hydrogen bond net than that observed for bis-imide A, except with the D heterocycle for which only one hydrogen bond is formed via the intermediate of a water molecule between the lower nitrogen atom and the amine of the side chain of Lys ${ }^{132}$ and the carboxylate of the side chain of $\mathrm{Glu}^{91}$. This could account for the lower Chk1 inhibitory activity of granulatimide. With isogranulatimide (Fig. 4D) which also showed a similar mode of binding, a hydrogen bond is observed between the nitrogen atom of the imidazole and the amino group of $\mathrm{Lys}^{38}$. The crystal structure of isogranulatimide/ Chk1 complex shows differences with what was obtained by molecular modelling. Three hydrogen bonds are observed between the ATP binding site of Chk1 and the drug: the two classical hydrogen bond with the imide heterocycle $\mathrm{E}$ and another one between one of the nitrogen atoms of the imidazole and the carboxylic acid of the side chain of Glu ${ }^{17}$ (Jiang et al., 2004).

Interestingly, the two hydrogen bonds formed with the NH and with the carbonyl on the left of the E heterocycle are always found in the crystal structures of Chk1 inhibitors in complex with Chk1. These hydrogen bonds are also observed between the lactam $\mathrm{NH}$ and $\mathrm{CO}$ of $\mathrm{UCN}-01$ and staurosporine with the
ATP binding site of the CDK2 kinase (Gray et al., 1999). Accordingly, the poor Chk 1 inhibitory activities of compounds, in which the upper imide nitrogen is substituted, are not surprising.

Concerning the cytotoxicities, except for compounds B, $\mathbf{4}$ and $\mathbf{5}$ the cytotoxicities toward the tumor cell lines tested are moderate. Chk1 inhibitors are not expected to be cytotoxic by themselves. Theoretically, Chk1 inhibitors are expected to be cytotoxic in the presence of a DNA-damaging agent. However, the low cytotoxicities of the most potent Chk 1 inhibitor in this series could be explained by their possible instability inside the cells. This family of compounds seems to be sensitive to nucleophilic reagents and their sensitivity seems to vary according to the substituents on the indole unit. It could be possible that the cytotoxicity observed is due to breakdown products rather than to the presumed compounds. This hypothesis is currently under investigation.

\section{References}

Anderson, H.J., Andersen, R.J., Roberge, M., 2003. Inhibitors of the G2 DNA damage checkpoint and their potential for cancer therapy. In: Meijer, L., Jézéquel, A., Roberge, M. (Eds.), Progress in Cell Cycle Research, vol. 5, pp. $423-430$.

Berlinck, R.G.S., Britton, R., Piers, E., Lim, L., Roberge, M., Moreira da Rocha, R., Andersen, R.J., 1998. Granulatimide and isogranulatimide, aromatic alkaloids with G2 checkpoint inhibition activity isolated from the Brazilian ascidian Didemnum granulatum: structure elucidation and synthesis. J. Org. Chem. 63, 9850-9856.

Chen, P., Luo, C., Deng, Y., Ryan, K., Register, J., Margosiak, S., TempczykRussell, A., Nguyen, B., Myers, P., Lundgren, K., Kan, C.C., O’Connor, P.M., 2000. The 1.7 ? crystal structure of human cell cycle checkpoint kinase Chk 1 : implications for Chk1 regulation. Cell 100, 681-692.

Davies, S.P., Reddy, H., Caivano, M., Cohen, P., 2000. Specificity and mechanism of action of some commonly used protein kinase inhibitors. Biochem. J. 351, 95-105.

Gray, N., Détivaud, L., Doerig, C., Meijer, L., 1999. ATP-site directed inhibitors of cyclin-dependent kinases. Curr. Med. Chem. 6, 859.

Hénon, H., Messaoudi, S., Hugon, B., Anizon, F., Pfeiffer, B., Prudhomme, M., 2005. Synthesis of granulatimide bis-imide analogues. Tetrahedron 61 , $5599-5614$

Hénon, H., Anizon, F., Pfeiffer, B., Prudhomme, M., 2006a. Synthesis of dipyrrolo[3,4- $a ; 3,4-c]$ carbazole-1,3,4,6-tetraones bearing a sugar moiety. Tetrahedron $62,1116-1123$.

Hénon, H., Anizon, F., Kucharczyk, N., Loynel, A., Casara, P., Pfeiffer, B., Prudhomme, M., 2006b. Expedited synthesis of substituted dipyrrolo[3,4- $a$; $3,4-c$ carbazole-1,3,4,6-tetraones structurally related to granulatimide. Synthesis $711-715$.

Hénon, H., Anizon, F., Golsteyn, R.M., Léonce, S., Hofmann, R., Pfeiffer, B., Prudhomme, M., 2006c. Synthesis and biological evaluation of new dipyrrolo[3,4- $a ; 3,4-c]$ carbazole-1,3,4,6-tetraones substituted with various saturated and unsaturated side chains via palladium catalysed cross-coupling reactions. Bioorg. Med. Chem. 14, 3825-3834.

Hugon, B., Pfeiffer, B., Renard, P., Prudhomme, M., 2003a. Synthesis of isogranulatimide analogues possessing a pyrrole moiety instead of an imidazole heterocycle. Tetrahedron Lett. 44, 3927-3930.

Hugon, B., Pfeiffer, B., Renard, P., Prudhomme, M., 2003b. Synthesis of granulatimide analogues bearing a maleimide instead of an imidazole heterocycle. Tetrahedron Lett. 44, 3935-3937.

Hugon, B., Pfeiffer, B., Renard, P., Prudhomme, M., 2003c. Synthesis of isogranulatimides A and B analogues possessing a 7-azaindole unit instead of an indole moiety. Tetrahedron Lett. 44, 4607-4611.

Jiang, X., Zhao, B., Britton, R., Lim, L.Y., Leong, D., Sanghera, J.S., Zhou, B.B.S., Piers, E., Andersen, R.J., Roberge, M., 2004. Inhibition of Chk1 by the G2 
DNA damage checkpoint inhibitor isogranulatimide. Mol. Cancer Ther. 3, 1221-1227.

Léonce, S., Pérez, V., Casabianca-Pignède, M.R., Anstett, M., Bisagni, E., Atassi, G., 1996. In vitro cytotoxicity of S16020-2, a new olivacine derivative. Invest. New Drugs 14, 169-180.

Luo, Y., Rockow-Magnone, S.K., Kroeger, P.E., Frost, L., Chen, Z., Han, E.K.H., Ng, S.C., Simmer, R.L., Giranda, V.L., 2001. Blocking Chk1 expression induces apoptosis and abrogates the G2 checkpoint mechanism. Neoplasia 3 , 411-419.

Molinari, M., 2000. Cell cycle checkpoints and their inactivation in human cancer. Cell Prolif. 33, 261-274.

Piers, E., Britton, R., Andersen, R.J., 2000. Improved synthesis of isogranulatimide, a G2 checkpoint inhibitor. Syntheses of didemnimide C, isodidemnimide A, neodidemnimide A, 17-methylgranulatimide, and isogranulatimides A-C. J. Org. Chem. 65, 530-535.

Prudhomme, M., 2004. Combining DNA damaging agents and Chk1 inhibitors. Curr. Med. Chem.-Anti-Cancer Agents 4, 435-438.

Prudhomme, M., 2006. Novel Chk1 inhibitors. Recent Patents on Anti-Cancer Drug Discovery, 1, 55-68.

Roberge, M., Berlinck, R.G.S., Xu, L., Anderson, H.J., Lim, L.Y., Curman, D., Stringer, C.M., Friend, S.H., Davies, P., Vincent, I., Haggarty, S.J., Kelly, M.T., Britton, R., Piers, E., Anderson, R.J., 1998. High-throughput assay for G2 checkpoint inhibitors and identification of the structurally novel compound isogranulatimide. Cancer Res. 58, 5701-5706.
Suganuma, M., Kawabe, T., Hori, H., Funabiki, T., Okamoto, T., 1999. Sensitization of cancer cells to DNA damage-induced cell death by specific cell cycle G2 checkpoint abrogation. Cancer Res. 59, 5887-5891.

Tao, Z.F., Lin, N.H., 2006. Chk1 inhibitors for novel cancer treatment. AntiCancer Agents Med. Chem. 6, 377-388.

Walworth, N., Davey, S., Beach, D., 1993. Fission yeast chk1 protein kinase links the rad checkpoint pathway to cdc2. Nature 363, 368-371.

Wang, L., Liu, X., Chen, R., 2003. Derivatives of isoindigo, indigo and indirubin and use in treating cancer, International patent WO03051900, CA 139:47135.

Yoshida, T., Nishiyachi, M., Nakashima, N., Murase, M., Kotani, E., 2002. New synthetic route to granulatimide and its structural analogues. Chem. Pharm. Bull. 50, 872-876.

Yoshida, T., Nishiyachi, M., Nakashima, N., Murase, M., Kotani, E., 2003. Synthesis of granulatimide positional analogues. Chem. Pharm. Bull. 51, 209-214.

Zhao, B., Bower, M.J., McDevitt, P.J., Zhao, H., Davis, S.T., Johanson, K.O., Green, S.M., Concha, N.O., Zhou, B.B.S., 2002. Structural basis for Chk1 inhibition by UCN-01. J. Biol. Chem. 277, 46609-46615.

Zhou, B.B.S., Elledge, S.L., 2000. The DNA damage response: putting checkpoints in perspective. Nature 408, 433-439. 